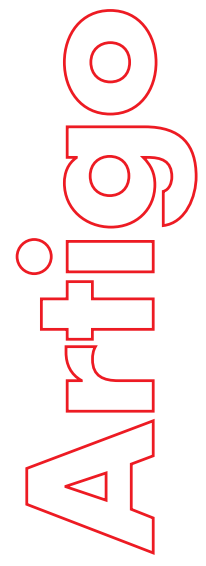

\title{
UNSUSTAINABLE URBAN SPRAWL IN BRASILIA DF - LUZIÂNIA, ÁGAS LINDAS DE GOIAS AND VALPARAISO DE GOIAS 2003-2014
}

\author{
Yvette Mónica Carrillo Salomón
}

p. $50-70$

http:// Como citar este artigo:

Salomón. Y, M, C. UNSUSTAINABLE URBAN SPRAWL IN BRASILIA DF - LUZIÂNIA, ÁGUAS LINDAS DE GOIÁS AND VALPARAÍSO DE GOIÁS 2003-

Revista Eletrônica: Tempo - Técnica - Território, v.6, n.2 (2015), p.

50:70 ISSN: 2177-4366. DOI: https://doi.org/10.26512/ciga.v6i2.21943

Disponível em: http://periodicos.unb.br/index.php/ciga/

Este obra está licenciado com uma Licença Crea tive Commons Atribuição-NãoComer cial 4.0 Inter nacional. 


\title{
UNSUSTAINABLE URBAN SPRAWL IN BRASILIA DF - LUZIÂNIA, ÁGUAS LINDAS DE GOIÁS AND VALPARAÍSO DE GOIÁS 2003-2014
}

\section{Yvette Mónica CarrilloSalomón}

Doutoranda pelo Departamento de Geografia da Universidade de Brasília (UnB). Mestre em Urbanismo pela Universidade de Brasília (UnB). Mestre em Urbanismo e Organização do Território pela Universidade Libre de Bruxelas (ULB). Graduada em Arquitetura e Urbanismo pela Universidade Nacional Federico Villarreal - Lima (UNFV) e Graduada em Informática pela CommunautéFrançaise de Belgique (EPFC)

yvette.carrillo@gmail.com

\begin{abstract}
This article examines the urban expansion on Brazilian areas: Federal District, Luziânia, ÁguasLindasand Valparaíso de Goiás, in the period from 2003 to 2014. The study was conducted using the technological platform of ArcGis 10.1 which was employed to help in theanalysis of the urban sprawl. The result showed that the urban expansion evolves unsustainably lacking urban and environmental planning. This fact places a considerable risk not only the environmental balance but also the health of the dwellers in these places and surroundings.
\end{abstract}

Keywords: urban sprawl, unsustainability, environmental risk.

RÉSUMÉ : Dans cet article est étudié l'expansion urbainedans le District Fédéral du Brésil, et les communes de Luziânia, Águas Lindas de Goiás et Valparaíso de Goiás entre les années 2003 et 2014. L'étude a été réalisée à l'aide de la plate-forme technologique d'ArcGIS 10.1 qui a contribué à l'analyse de l'expansion. Le résultat a montré que cette expansion évolue de façon non durable par le manque de planification urbaine et environnementale, ce qui met en risque non seulement l'équilibre milieu naturel, mais aussi la santé de la population locale et de l'entourage.

Mots-clés : expansion urbaine, non-durabilité, risques environnementaux.

RESUMEN: En el presente artículo se estudia la expansión urbana en el Distrito Federal de Brasil, Luziânia , Aguas Lindas de Goiás y Valparaísode Goiás entre los años 2003 y 2014. ayudó al análisis de la expansión El estudio se realizó utilizando la plataforma tecnológicaArcGIS10.1 que ayudó al análisis de la expansión. El resultado mostró que dicha expansión urbana evoluciona de forma insostenible por la falta de planificación urbana y ambiental, lo que pone en riesgo considerable no sólo el equilibrio del medio ambiente, sino también la salud de la población local y la del entorno.

Palabras clave: expansión urbana, insostenibilidad, riesgo ambiental. 


\section{Introduction}

At present, most Brazilian cities suffers spatial problems arising from the continued expansion of urban peripheries with a standard of absolute socio-spatial segregation, and investments only in the hegemonic city, called by Ferreira (2011) the uneven urbanization model.In the urban sprawl dynamics interfereactors with ownand specific characteristics making the tracking of the urbanization process complicated,where urban and environmental sustainability concepts remain in the background.

Over time, the poor population unable tosettle into the city through a legal occupation of urban space, without conditions to acquire a residence in the legal market, had no choice but to occupy land illegally,located in less valued areas because of restrictions on legal occupation. Restrictions mostly due to potential risksor the need for environmental preservation.These occupations ignore urban and environmental regulations and have severe consequences, affecting the environmental balance and the well-being of the local population and its surroundings (PESTANA, 2006).

According Maricato (2001) the main cause of environmental unsustainability in Brazilian cities is the uneven process of urban space production, where legalized urban occupation is limited to a minority that can afford the high price of this product.

This article presents a study of urban sprawl in the Brazilian Federal District, Luziânia, ÁguasLindasde Goiás and Valparaiso de Goiás between year 2003 and 2014 with the help of ArcGIS 10.1 technology platform.

First at all, with the help of the tools of ArcGIS 10.1 software, the urban area under study was digitalizedfrom two different years: 2003 and 2014 in order to recognize howthe areas wereexpanded in this period.Secondly, the expansion of these locations was analyzed. To do so, it was made a comparative analysis of urban sprawl according to urban density (following built surface visualized). In the digitalization were considered three types of density: high density (ad), medium density (md) and low density (bd).Next, in order to compare the urban sprawl of each district in the studied areas, a chart was filled showing the districts and the corresponding expansion. Then,some environmental impacts resulting from the sprawl were highlighted comparing these results with other studies in the area.Finally, some recommendations resulting from the study were made.

There were used SatelliteImagery: Lansat 7 for the image of the 2003 and Lansat 8 for 2014 taken from the US Geological Survey website (U.S.G.S, 2014). The images were projected for WGS_1984_UTM_Zone_23S geographic coordinates system. In this way, it was made the 
digitalization from urban areas in the two dates mentioned, whichsignificantly helped determine the sprawl and its impact in the period 2003-2014.

\section{Housing Problems}

In recent decades, humanity witnesses a drastic population exodus from rural to urban areas in different parts of the globe.In 2014, 54\% of the world's population, approximately 3.5 billion people, was already living in urban areas. According to theUnited Nations (2014)almost half of this population lives in cities with less than 500,000 inhabitants. Unfortunately, despite the comparative advantage of cities, urban areas are more inequitable than rural areas and there are millions of people living in extreme poverty in urban areas, where 828 million people live in slums and the number continues to rise (UN, 2015).

In a world increasingly globalized and interconnected as today there is still substantial differences in the urbanization levels among countries, and as the world continues to urbanize, the sustainable development challenges are greatest, especially in those lower-middle income countries where urbanization rate grows faster.It is expected that by 2050 the increase in urban population will be between 5600 and 7100 million people, the equivalent to between $64 \%$ and $69 \%$ of world population (UNITED NATIONS, 2014)

Brazilian cities are found within this trend developing in recent decades a growth model whose main features are the irregularity, informality and illegality.Is irregular because the land use infringes the regulatory framework, informal because the conditions promote participation in clandestine activities, and illegal because there is no property title among other factors.

To count this type of occupations, the Brazilian Institute of Geography and Statistics - IBGE considers a particular census tract called aglomerado subnormal(substandard settlements).

This sector is determined by a set of housing unitsestablishedin land other people's property,usually arranged in a disorganized and compactly way, and mostly lacking in essential public services.The IBGE (2010) estimated 11,425,644 people living in substandard settlements according to the latest census and by the way, itstated (IBGE, 2012) that only $56.8 \%$ of permanent households in 2009 were considered adequate for housing. The IBGE consider adequatehouseholds those that meet the following criteria: density, up to 2 people per bedroom;garbage collection service (directly or indirectly); water supply network; and sewage collection system or septic tank.

The indicator above-mentioned expresses the proportion of households that comply with the four criteria listed in the total of permanent households. Thus, the occupation of urban land being informal, irregular or illegal and inadequate housing is a major problem that involve about million people.

Eletronic Magazine: Time - Techinique - Territorry, V.6, N.2 (2015), 51:70 ISSN: 2177-4366 


\section{Exclusion in urban related issues}

The land occupation with features above described are the result, on the one hand, of exclusionary policies that contributed to unfair conditions of economic growth and distribution of wealth and on the other hand, the failure of urban authorities (SILVEIRA, 2016; PINTO, 2003; MARICATO, 1996). Typically, these occupations are established by illegal residents who occupy public or private land, or land environmentally vulnerable. In most cases, these residents delimit lots and begin to build rudimentary dwellings where public services such as water supply and sanitation,paving and street lighting do not exist.Over time, the buildings are extended, temporary building materials are replaced with others more durable and some public services begin to appear stimulating in that way the construction of more buildings and thepropagation of this same process in other locations within the city.

In many cases, slums and tenements do not have sewage,becomingfavorable areas for the spread of diseases, and the treated water is installed only in scattered spots.

Substandard settlementsare more likely to experience exclusion from the guaranteed areas of employment. The segregated inhabitants are physically and intellectually disable of producing. Not producing they are sentenced to unemployment. (PAVIANI, 2006).

The lack of an urban policy clearly defined by the Government for the Brazilian territory has led to an anarchic growth, increased urban density and deterioration of cities (ANJOS, 1993, p. 7).

In response to these problemsthere have been many improvements in the field of urban management, especially in the recognition of the right to housing and to the city, and the inclusion of the excluded people as subject of urban policies.

In the legal field, the experience showed that the only way to achieve the urban and land regularization process of these illegal land occupations would be by formalizing more flexible parameters of parceling andland use,in order to be more compatible with the particularities of theseseizures,so as to ensure the improvement of the livingstandards of local residents through investments in infrastructure.

This process resulted in the formulation and adoption of a more flexible legislation that allowed the land regularization of such settlements. The so-called law Estatuto daCidade (BRASIL, 2001), Federal Law $\mathrm{n}^{\mathrm{o}}$ 10.257, July 10, 2001 together withFederal Law $\mathrm{n}^{\circ}$ 11.977, July 7,2009ProgramaMinha Casa, Minha Vida - PMCMV (BRASIL, 2009)and the Law $n^{\circ} 12.608$, April 10, 2012 Política Nacional de Proteção e Defesa Civil - PNPDEC (BRASIL,2012) brought new approaches to the treatment of land tenure in the country.

Eletronic Magazine: Time - Techinique - Territorry, V.6, N.2 (2015), 51:70 ISSN: 2177-4366 
RegularizaçãoFundiáriais a specific term for a number of intervention measures in areas where its residents have no property title,slum dwellings, there is a lack of essential public services and can be establish in areas of risk and environmental fragility, among other issues.

The Estatuto da Cidadeestablishes a new era for urban land regularization since for the first time procedures, responsibilities and above all, important legal instruments such as Special Areas of SocialInterest - ZEIS ( stand for Zonas Especiais de Interesse Socialin Portuguese) are set out for its implementation, including the possibility of regularizing in Permanent Preservation Areas - PPAs requiring for this purpose a technical study for which a mapping and environmental monitoring are mandatory.

There is also the point that urban expansion due to processes of social exclusion often has a direct impact on areas that are important for environmental conservation (CODO, 2013), in addition to the risk areas. The fact is that the occupation of these environmentally fragile areas such as border streams, sliding slopes, floodplains, springs protected areas, wetlands, etc. are the alternative to people excluded from the market and from thecomprehensive public programs (BRAZIL, 2010). In consequence,residents live with high levels of vulnerability to natural disasters.

\section{Sustainable Development}

Environmental concerns have increased dramatically in recent years and are now among the biggest challenges that affect the general welfare as it has been found that in addition to climate change several environmental problems such as air and water pollution, water shortages, soil erosion, deforestation and loss of biodiversity among others are becoming more serious.

In the early eighties, to deal withthe ever-increasingly environmental problems, in order to analyze and formulate realistic proposals on environmental issues and plan new forms of international cooperation in this field, the United Nations organization creates the World Commission on Environment and Development chaired by the Norway Prime Minister Gro Harlem Brundtland. The result was theBrundtland Report - Our Common Future - 1987, which define for the first time the termsustainable development (UNITED NATIONS, 1987).

Sustainable development recognizes that growth must be both inclusive and environmentally sound to reduce poverty and build shared prosperity for today's population and to continue to meet the needs of future generations(WORLD BANK, 2015).

With regard to the urban issue, the Brundtland Report (UNITED NATIONS, 1987) emphasized that the development of a city must give priority to meet the basic needs of citizens offering them a better quality of life. 
Urban sustainability should include ethics, equity, democracy, cultural diversity and selfsufficiency (ACSERALD, 2001), must have a multidimensional character: promoting access to all equally, establish the connection between people and the natural environment, promoting the maintenance of historical and cultural heritage (SCHUSSEL, 2004); it must be based on a planning with public participation that promotes social justice to ensure equitable access to environmental resources.

In the HDR (2014) it is stated that real progress in human development is not just a matter of expanding the options for taking crucial decisions, the opportunity to acquire knowledge, and be healthy and feel safe, but it is also a question of how secure are these achievements and if these conditions are sufficient for a sustainable human development.

A sustainable city meets the needs of its citizens without exhausting the resources of future generations carefully managing the demand of resources and maximizing the efficiency of their use (MAGALHÃES, 2006).It is under this concept that the unsustainability in the urban expansion of the area under study is pointed.

\section{Areaunder study}

Areas localized in the RIDE-DF ${ }^{1}$ will be considered. The Integrated Regions of Development - RIDEs(stand for RegiõesIntegradas de Desenvolvimento in Portuguese) are Brazilian metropolitan areas located in more than one federal unit. They were created as a decentralization strategy,so that the state not be anymore the only provider of public goods and servicescreating networks of cooperation between the states and municipalities.

The RIDEs seek to promote development by investments of public funds in different sectors such as road system, transport; public utilities; basic sanitation; use, subdivision and occupancy of land; environment protection; use of water and mineral resources; public housing; fighting the poverty and marginalization factors; telecommunications services; tourism and public security, among others(BRASIL, 2011).

The RIDE- DF isconstitutedbythe Federal District, Goiásmunicipalities: Abadiânia, Água Fria de Goiás, Águas Lindas de Goiás, Alexânia, Cabeceiras, Cidade Ocidental, Cocalzinho de Goiás, Corumbá de Goiás, Cristalina, Formosa, Luziânia, Mimoso de Goiás, Novo Gama, Padre Bernardo, Pirenópolis, Planaltina, Santo Antônio do Descoberto, Valparaíso de Goiás e Vila Boa; andMinas Geraismunicipalities: Unaí, Buritis e Cabeceira Grande (BRASIL, 2015).Created by Complementary Law No. 94 February 19, 1998 and regulated by Decree No. 7469 May 4,2011,

\footnotetext{
${ }^{1}$ Integrated region ofdevelopment of the Federal District and surroundings.
} 
aims to reduce regional inequalities caused by high urban concentration, minimize the demand pressures to get utilities and reduce the difficulty of obtain them from the public sector. The RIDEDF articulate administrative actions to promote projects aimed at supporting economic revitalization and the provision of necessary infrastructure for the development on a regional scale (MINISTÉRIO DE INTEGRAÇÃO NACIONAL, 2015).

Although the goal of the RIDE- DF was to reduce regional inequality and minimize problems on the demand of public services, now this goal has not been reached presenting a peculiar situation by means of therelationship between two municipalities plus the Federal District.

So, its management can only be done at the federal level, which culminates in the length of proceedings related to the region development,resulting in an unsuccessful development or a development that is too small to be considered as a good product (RIBEIRO, 2013, own translation).

This study is focused on the area of the Brazilian Federal District and the municipalities of Luziânia (the fifth most populous city in the state), with a population estimated at 191,139 inhabitants, Valparaíso de Goiás, with an estimated population of 146,694 (the seventh most populous city Goiás) and ÁguasLindas de Goiás (the sixth most populous city in the state) with an estimated population of 182,526 according to the IBGE (2014). See Figure 1 (red line).

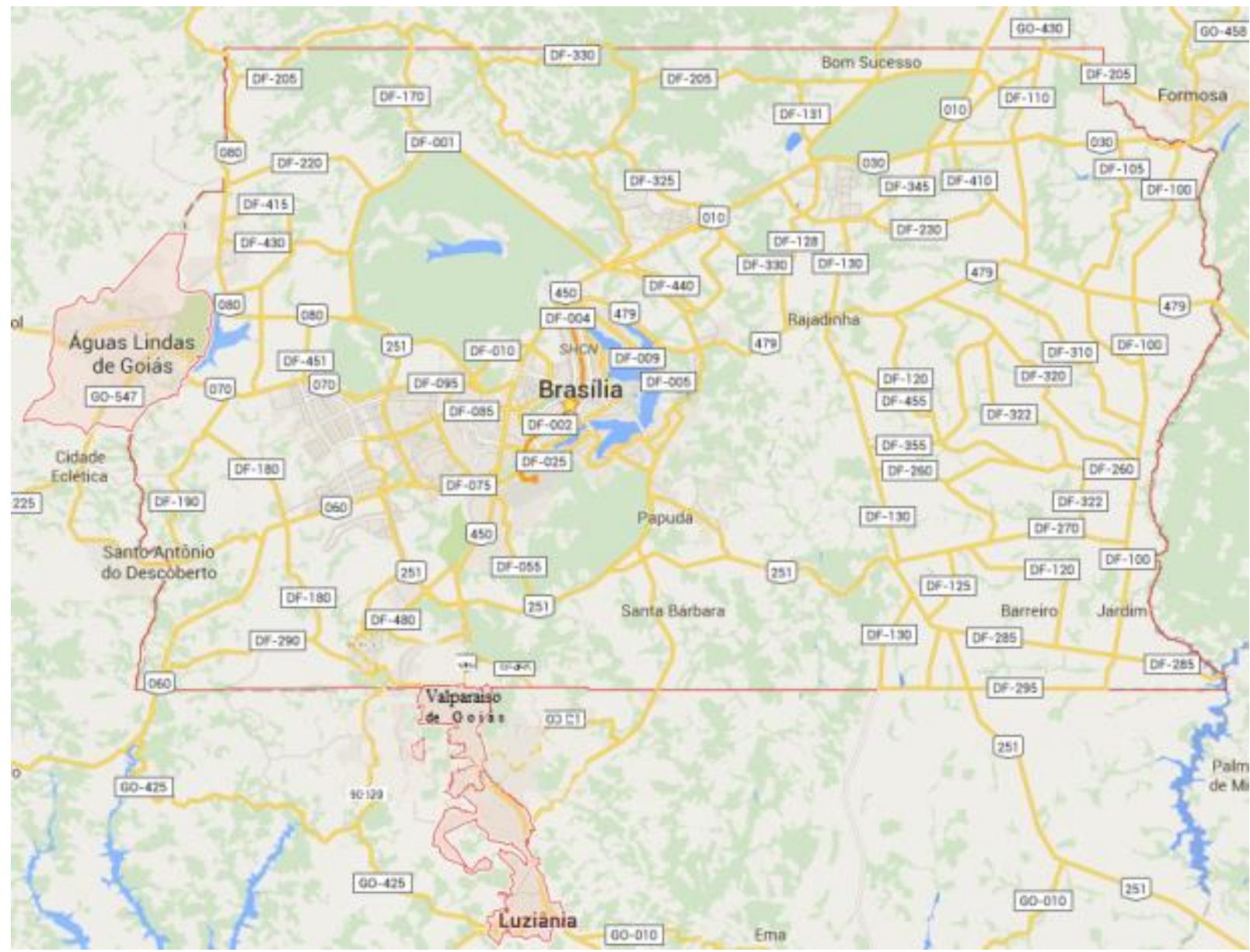

Eletronic Magazine: Time - Techinique - Territorry, V.6, N.2 (2015), 51:70 ISSN: 2177-4366 
Figure 1 - Location of the study area. Source: Author based on Google Maps.

\section{Urban sprawl in the areaunder study}

In Brasilia there are a wide variety of people from everywhere, all ages and generations, with a mixture of different accents of the country and even overseas totaling a population of $2,786,684$ inhabitants in the Federal District, and according to IBGE, it is estimated to be more than 3 million people in the capital in 2017. The current population density is $444.66 / \mathrm{km}^{2}$ and because of its rapid growth, it is the fourth most populous city in the country (GOVERNO DE BRASÍLIA, 2015).

The low integration on the national economy and the weak existing economic dynamism before the construction of Brasilia have influenced the development and the spatial configuration of the region.The Municipalities economy were based on mining activities and livestock production therefore had dispersed spatial configuration.

The Modern Movement, inherited by Brasilia, stimulated morphologies in the city where open spaces predominateoverbuilt spaces. The city is characterized by high fragmentation in its urban structure and large disparities in income distribution. Considering the average monthly income of the residents, the richest $10 \%$ concentrate $26.68 \%$ of income and the $10 \%$ of lower income people receive only $1.37 \%$. The Gini ${ }^{2}$ index is 0,389 . (CODEPLAN, 2014).

This situation is the result from the historical concentration of economic activities, and because most satellite towns were initially established as bedroom towns, lacking adequate urban structure.In the area it was generated an expansion process characterized by use and anarchic occupancy of land, and a fast demographic concentration subsequent of the construction of Brasilia, which led people to migrateto the satellite towns of the PlanoPilot or near the DF,in search of work and housing.In time, these conditions also affected the use and distribution of water resources, especially in the socio-economic inequality that began to be present in the basins that are shared with the DF, which are defined by the state limit (HERRERA; ALVES, 2015).

The concentration of administrative functions in Brasilia DF and large transfer of tax revenue received by it make the capital exerts a strong tertiary function, thereby attracting people in search ofjobs and services. At the same time, the existing surrounding cores had their old functions weakened and began to play an important role in absorbing this population attracted to the capital(CAIADO, 2004).

\footnotetext{
${ }^{2}$ Gini index measures the extent to which the distribution of income (or, in some cases, consumption expenditure) among individuals or households within an economy deviates from a perfectly equal distribution. It measures the area between the cumulative percentage of income and the cumulative percentage of the population. Ranging from "zero" (perfect equality) to "1" (perfect inequality).
}

Eletronic Magazine: Time - Techinique - Territorry, V.6, N.2 (2015), 51:70 ISSN: 2177-4366 
In recent years, satellite cities were growing rapidly in terms of population and economic relevance, resulting in high infrastructure requirements, services and job opportunities for its inhabitants.

In Brasilia are notorious the disparities between the pilot plan and satellite cities. In the last ones there is often a lack of infrastructure (paved roads, running water, sewage, etc.).In the PlanoPiloto live people with high incomes, in the satellite cities next to the Plano live peoplewith medium incomes, and far away livethe predominant population of low incomes. This situation presents a clear social stratification with a palpable territorial dimension.

Among the cities that have strong socioeconomic differences are ÁguasLindas do Goiás, characterized by high population density and high urban expansion and Santo Antônio do Descoberto,marked by poverty that is reflected in the lack of infrastructure and collective urban equipment, and consequently a low quality of life.

Figure 2 shows in purple color the digitalizationof the area under study based on satellite images: the DF,Luziânia, Valparaiso de Goiás andAguasLindas de Goiásin 2003 and 2014. It can be perceived the sprawl of the urban area during the study period.
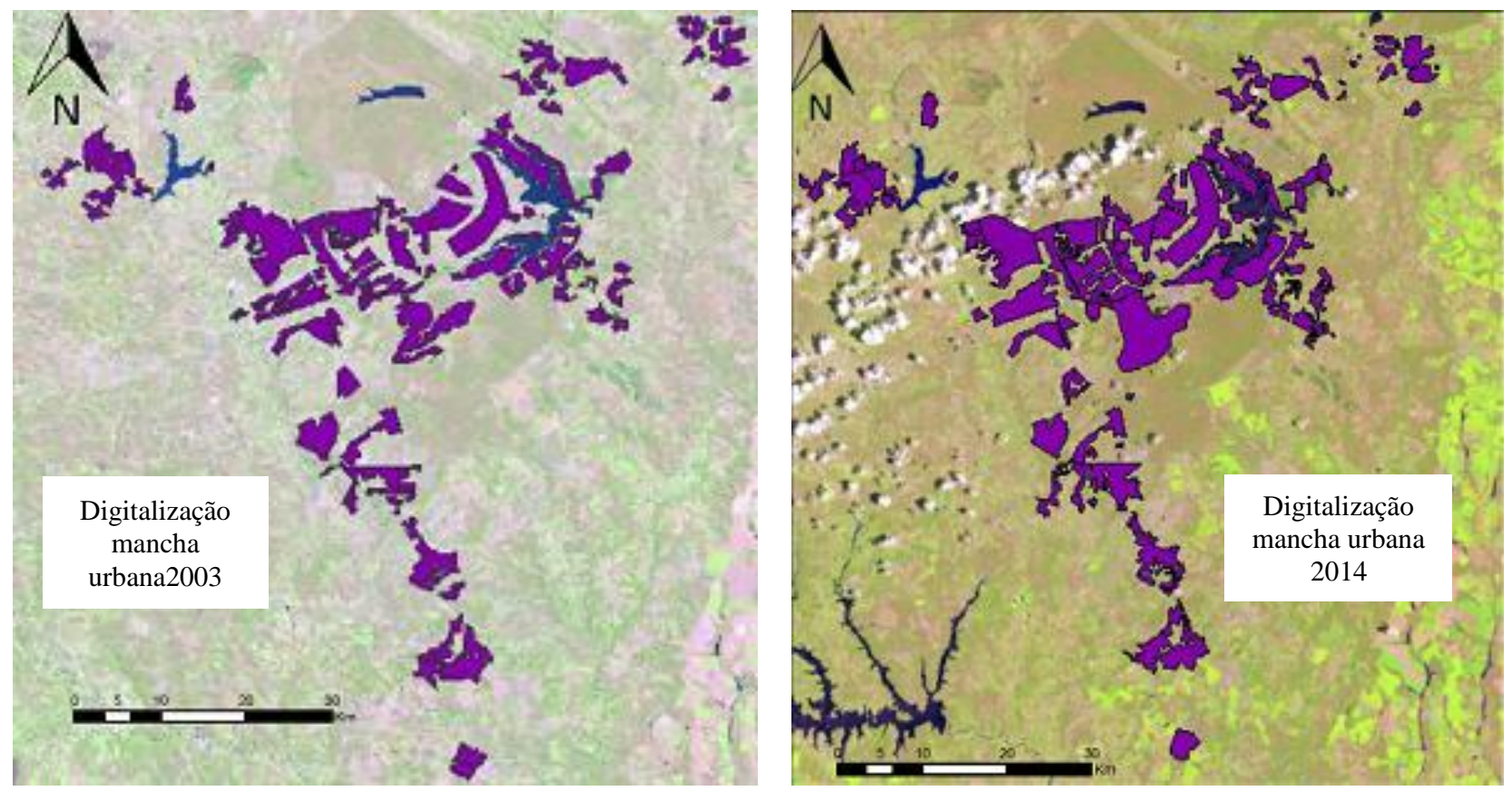

Figure2 - Digitalization 2003/2014.Source: Author

\subsection{Expansion - urban densities:}

In this study "urban density" refers to the built surfaces observed duringdigitalization.Figure 3 shows that the high density expansion (red) is prevalent in the Plano Piloto and part of Ceilândia. Regarding the expanded area of low density (pink) it is prevalent in ÁguasClaras and part of Park 
Way, and finally the expanded area withmedium density (yellow) is scattered throughout the study area.

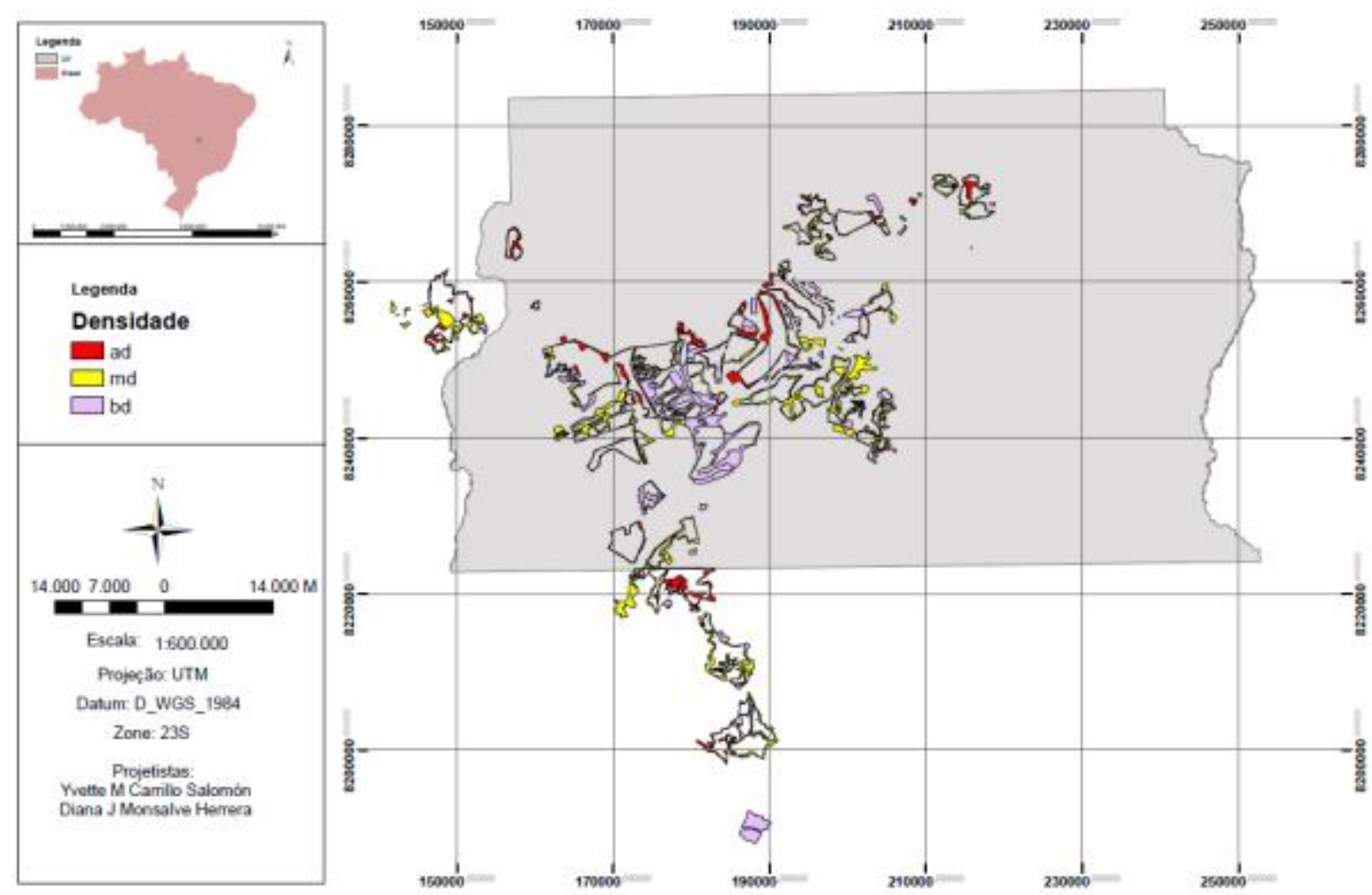

Figure 3 - Urban densities (high, medium, low) of the expanded studied areas between 2003/2014. Source: Author

In Figure 4, it is observed that theareas with low and medium urban density grewmore (around 80 square kilometers) thanareas of high urban density that expanded only half this size (about 40 square kilometers).

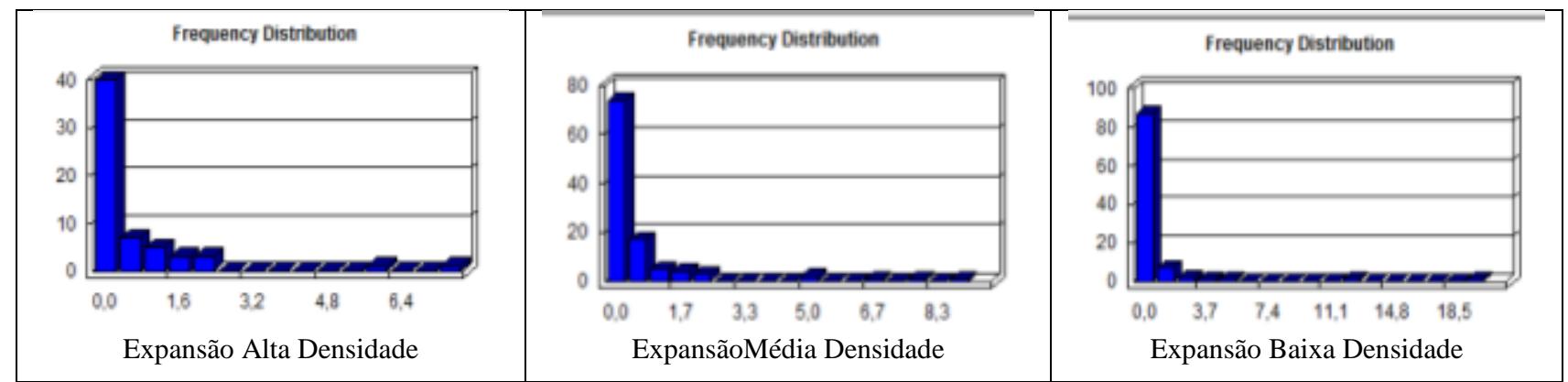

Figure 4 - Expansions per sq. km in the area under study. Source: Author

\subsection{Expansion by neighborhoods}

In Figure 5 it can be seen how the expansion was developed according to the neighborhoods studied:DF, Luziânia, Valparaiso e ÁguasLindas de Goiás. In this figure, it must be taken into account that in terms of expansion it was only considered the digitalized area. Thus we can see that the Luziânia municipality, located outside the DF, had greater urban sprawl with almost 24 square Eletronic Magazine: Time - Techinique - Territorry, V.6, N.2 (2015), 51:70 ISSN: 2177-4366 
kilometers added. Within the limits of the DF, Park Way increased the most with 20 square kilometers approximately and the lowest expansion was identified in the Park Way II with about .05 square kilometers. With these results it can be said that Brasilia has a scattered urban development.

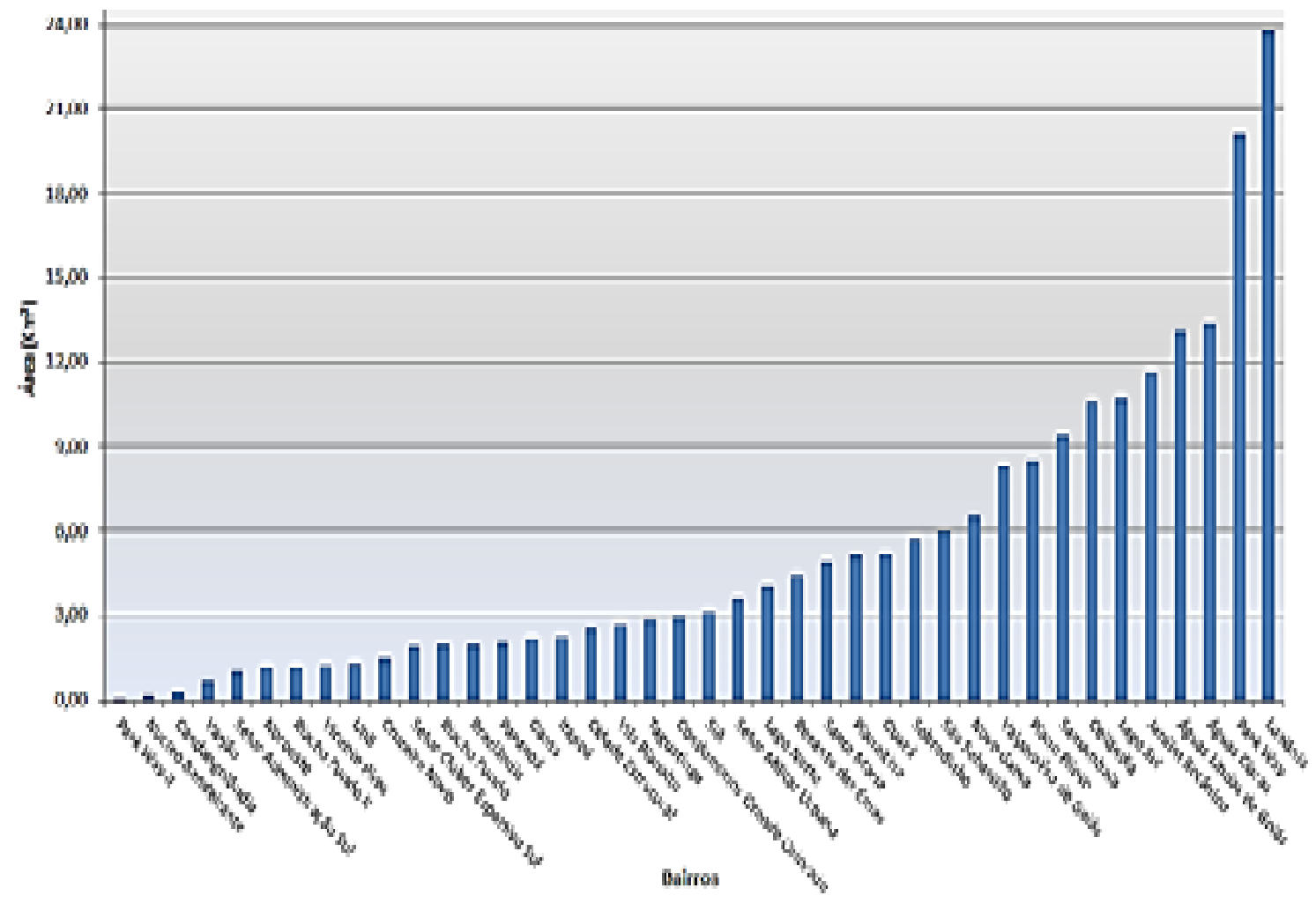

Figure 5 - Urban area expanded by neighborhoods. Source: Author

In Figure 6 can be identified the areas with irregular settlements in Brasilia DF in 2012, where an intense urban irregularity is detected. In this area the unsustainable process is recognized by an increase in urban sprawl identified in Figure 2. 


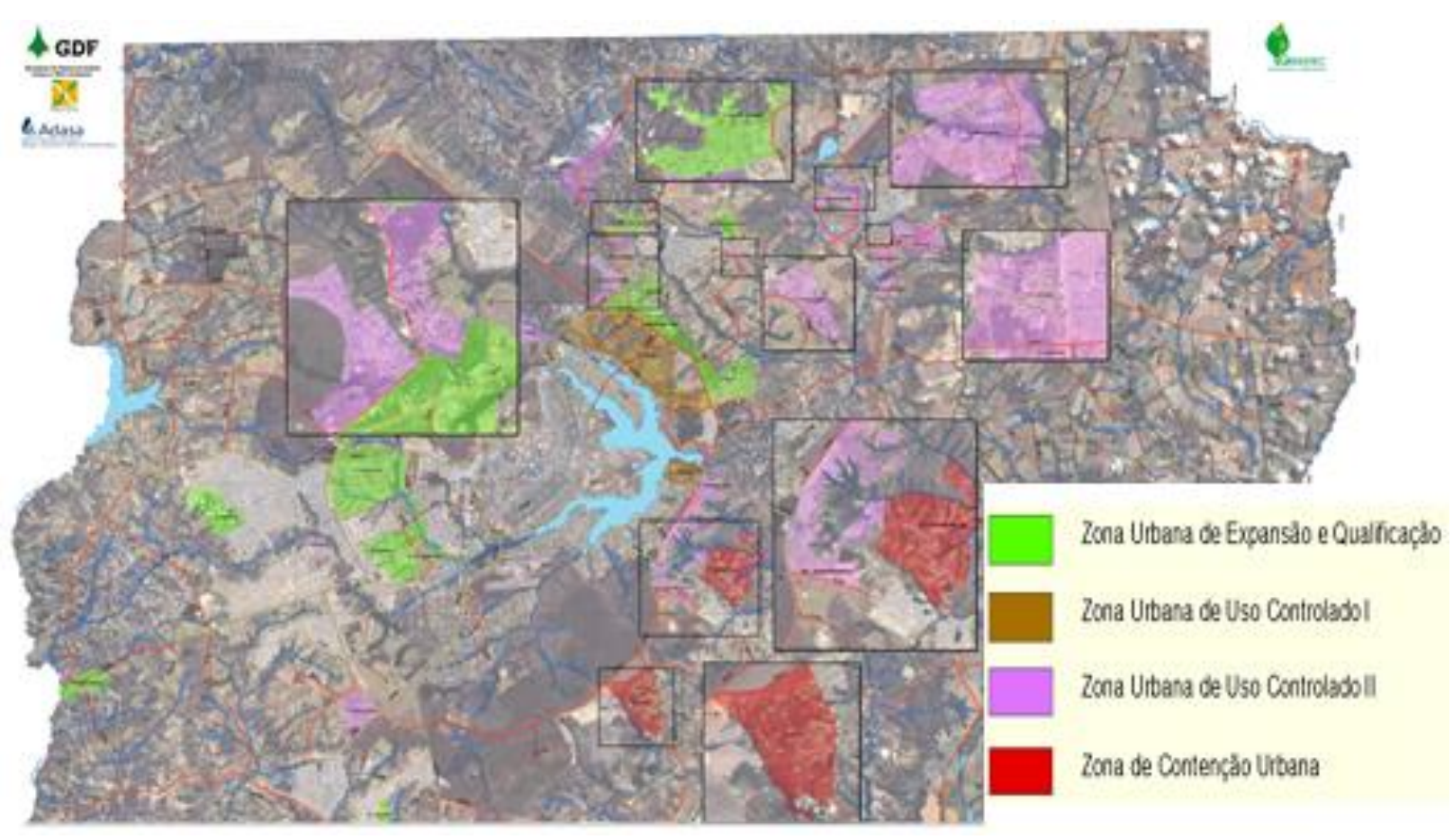

Figure 6 - Irregular plots in Brasilia DF. Source: ADASA and GDF, 2012

\section{Environmental impacts in the area under study}

Unsustainable environmental impact has been identified by the increase in urban sprawl in neighborhoods and cities studied as seen in Figure 2.Especially near streams. This expansion alters the hydrologic cycle of the area due to soil sealing increasing runoff areas and decreasing infiltration that feed surface water sources. The washed of sealed areas on rainy seasons can carry sediment and solid waste to the rivers and lakes increasing in that way the risk of contamination and adding bad elements such as phosphorus which could affect the qualitative conditions increasing the trend of eutrophication of lentic sources in the area. For example, in Photo 1 an urban area is invading and strangling the stream.This situation will generate increasing environmental problems resultingfrom the above mentioned situations.

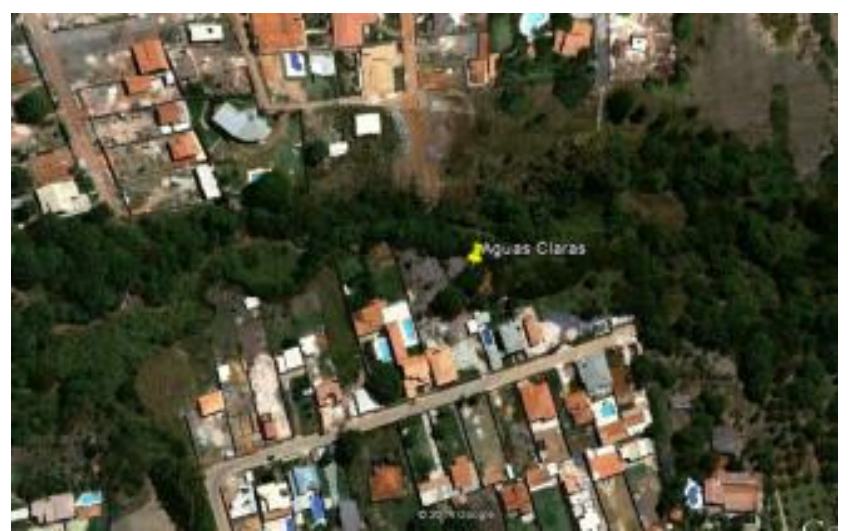

Photo1 - Environmental fragile area resulting from urban expansion. Source: GoogleEarth

Eletronic Magazine: Time - Techinique - Territorry, V.6, N.2 (2015), 51:70 ISSN: 2177-4366 
The general problem of urban unsustainability in the area can be appreciated in Figure 7
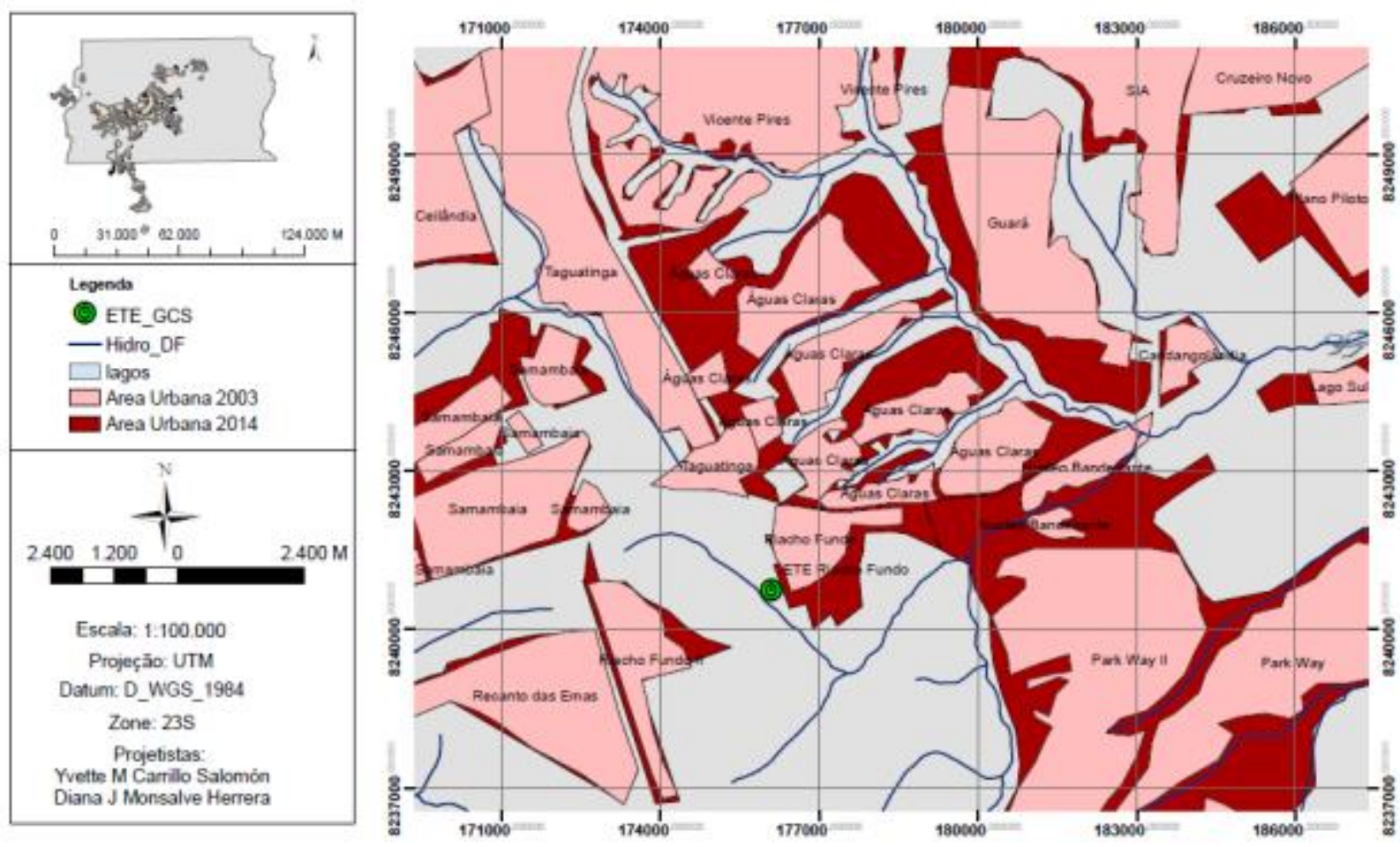

Figure7 - Detail of urban sprawl. Source: Author

This figure provides an overview of the occupations that have advanced to the shore of the streams on areas inappropriate for occupation in Vicente Pires and ÁguasClaras where the expansion of the urban area (in red) by the year 2014 has been significant with dangerous approach to water sources compromising the environmental balance. But even so, they continue to grow showing the lack of planning in the use of urban land, as mentionedin the Menezes study (2010) who points out that the urban growth trend is continuing in this area.

The Figure 8 shows the location of Sewage Treatment Plants - ETEs (stand for Estações de Tratamento de Esgotoin Portuguese) in the Federal District. It can be seen that the ETEs are close to Lago Descoberto, DF main source in addition to the Lago Paranoá, future source of the area under study.Also ETEs can be found in tributaries of lakes.

This study shows the increased urban sprawl and its densification near the ETEs and water sources.The environmental fragility in this area is greater due to increased sewage flow to be treated and therefore an increase of treated effluent in rivers flowing through urban areas. 


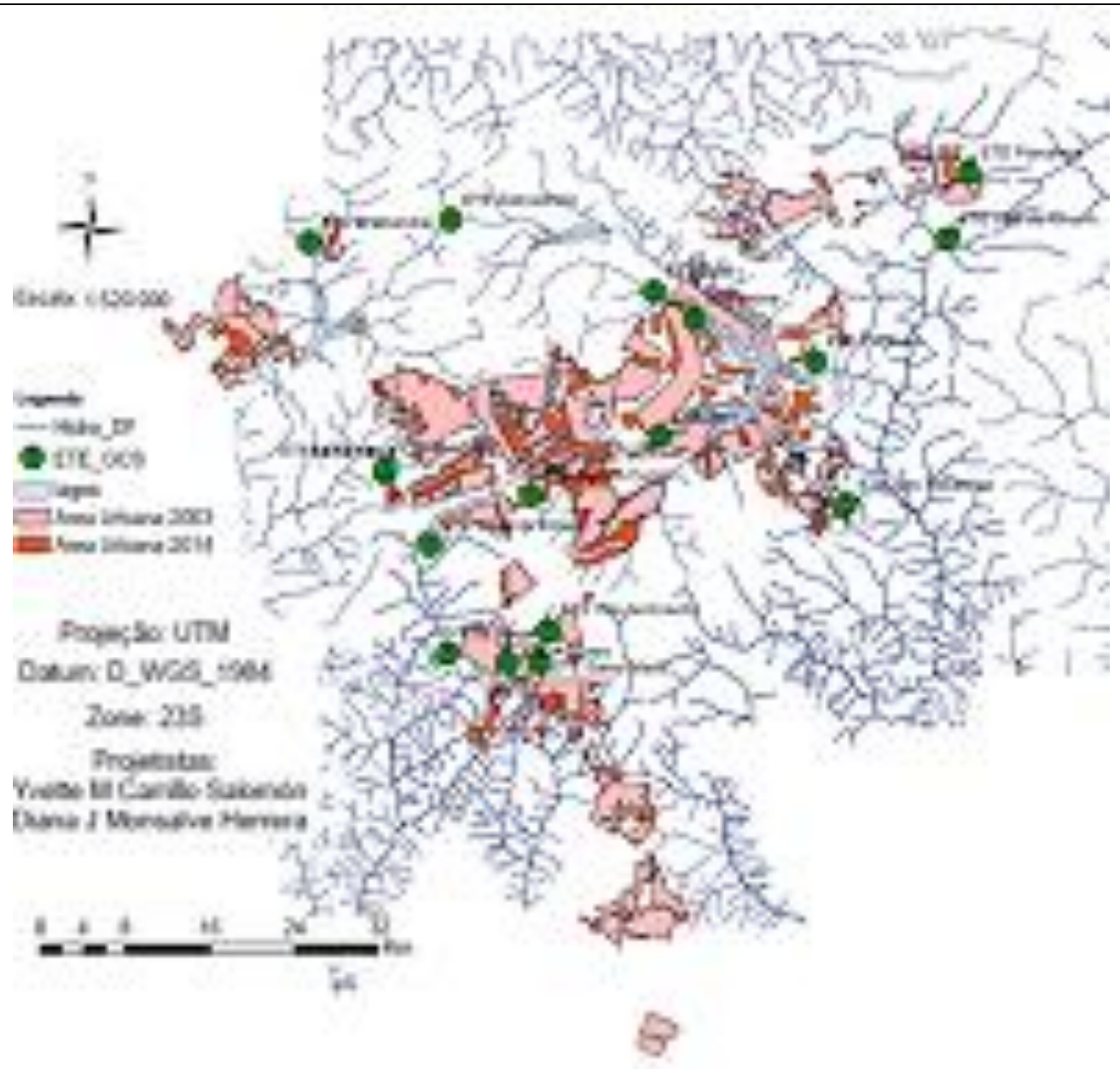

Figure 8 - Water sources and ETEs stablished near the expanded areas. Source: Author based in ADASA, 2012b.

In Figure 9 are presented different colored areas in Brasilia DF representing relationships between, on the one hand, high or medium intensity of urban occupation and, on the other hand,greater or lesser environmental sensitivity.It can be appreciated on this map that among the areas with greater environmental sensitivity and high intensity of urban occupation are the neighborhoods of Taguatinga, Ceilândia e Samambaia. In Figure 8 can be identified two ETEs (Samambaia e Melchior) near these locations which shows the high environmental fragility since the release of sewage becomes increasingly critical and must be treated. As for the areas of greater environmental sensitivity and medium intensity of urban occupation (Figure 9) mainly are areas of NúcleoBandeiranteand Park Way. It is important to remark that Park Way was identified in Figure 2 as having the largest urban expansion in the DF, confirming the impact that could be produced in that area. 


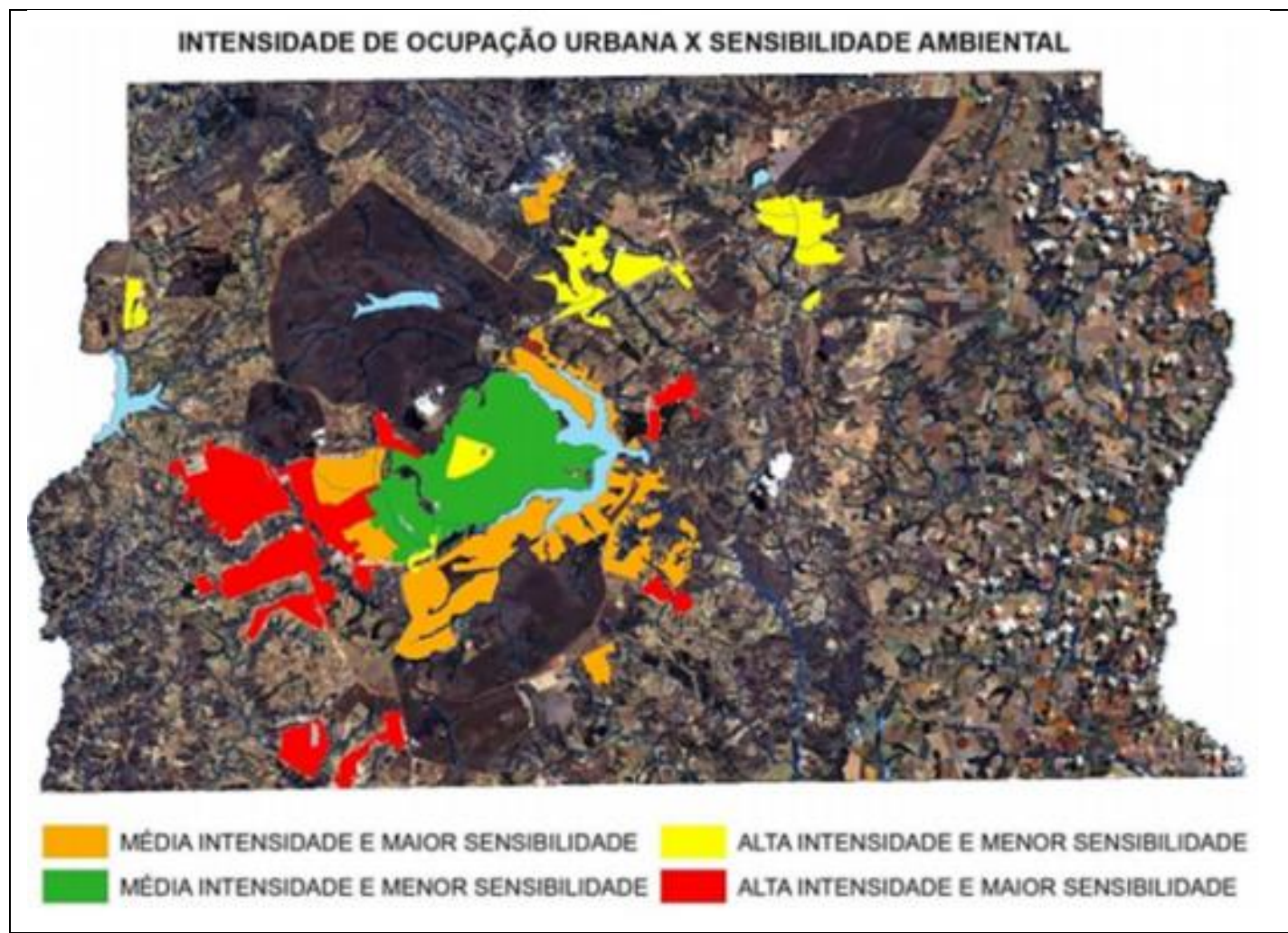

Figure 9 - Intensity of urban occupation vs environmental sensitivity. Source: ADASA and GDF, 2012a.

According to the study of the Integrated Management Plan for Water Resources of the Federal District (ADASA, 2012b) there is a pressure on urban infrastructure and services due to the increasing concentration of inhabitants in the urban areas and additionally, due to the financial inability of most municipalities, a deterioration of drinking water supply and sewage services are emphasized.

In the study by Ribeiro (2013) can also be highlighted that in the areas under study:Luziânia, ÁguasLindas and Valparaíso de Goiás environmental conditions are not the best and the situation of urban infrastructures are the worst of the area. See Figure 10.

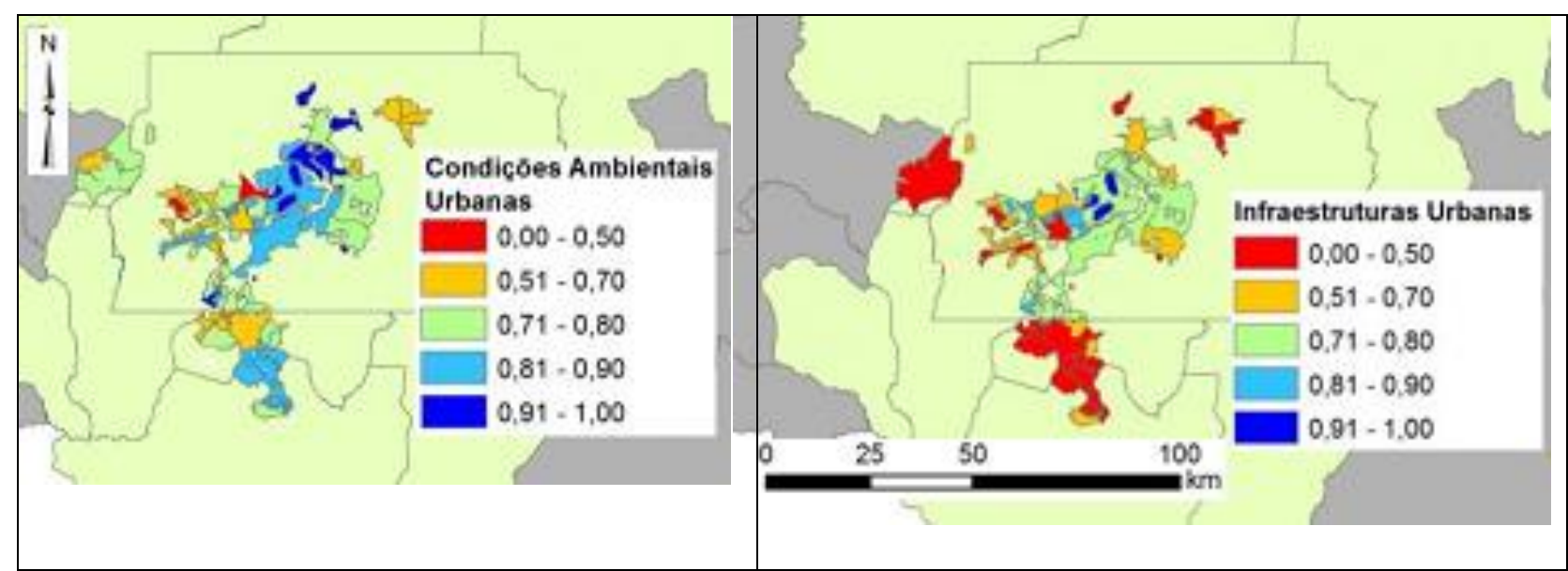

Figure 10: Urban Environmental Conditions and Urban Infrastructure in the area under study. Source: Ribeiro, 2013. Adapted by the author.

Eletronic Magazine: Time - Techinique - Territorry, V.6, N.2 (2015), 51:70 ISSN: 2177-4366 


\section{Study Results}

The above analysis demonstrates how urban sprawl between 2003 and 2014 had a significant increase in precarious and unplanned development resulting unsustainable in a long-term.

The result of the analysis of urban expansion byurban densities showed that the areas of low and medium density expanded the more, being their development not planned as confirmed by $\operatorname{ADASA}(2012 a)$.

This study concludes an increase of urban areas, especially areas with environmental fragility, where the springs are disappearing swallowed by the urban sprawl, which increases the risk of contamination of waters and serious effects on the remaining ecosystems.

It is evident,analyzing satellite photos, the unsustainability of the expansion mainly with regard to management and efficiency maximizing the use of existing resources, especially water. Environmental risks are evidentfor the new settlements especially those that extend dangerously close to the shore of the rivers like Vicente Pires, ÁguasClaras, Ceilândia e ÁguasLindas de Goiás which are the closest areas of water sources. This fact puts at increased risk water quality and consequently the health of the population and the environment.

It exists other disabilities resulting from the absence of urban planning such as lack of infrastructure, equipment, etc. besides other problems derived from this situation such as high rates of crime which according to the sociologist José Carlos Rassier are a result of the disorganizedgrowth of the city "the great mass coalesces around the wealthier cities, but not benefits of economic growth. This creates a social revolt, which generates violence" (CUNHA, 2014). While violence is not the focus of the present study it is considered a threat to the sustainability of the city.

\section{Final Considerations and Recommendations}

Whereas Brasilia belongs to the Central-West region it is interesting to know that the population of this region after the inauguration of the capital going from 2,678,380 people in 1960 to $14,058,094$ in 2010 , with population growth of $425 \%$ in this period (IBGE 2010).

But this growth was not homogeneous, obtaining the federal district the highest population density in the country as other states in the Central-West regionsuch as Mato Grosso, Mato Grosso do Sul and Goiás had only 3.36\%, 6.86\% and 17.65 respectively (IBGE, 2010). It is evident that without Brasilia this growth had not been the same, being there the highest number of jobs and services around this area (OBSERVATORIO DAS METROPOLIS, 2012).

This reality highlights the dependence from Brasilia compared to the rest of cities of its surroundings and if this data is combine with the fact that the city has large disparities in income distribution, that is, that the city operates with a very high degree of inequality, we have that the 
growth of Brasília was discriminatory. And, if adding to this that natural resources are not managed carefully as is the case of water, it could be concluded that is indispensable to adopt measures to control such unsustainable development.So it is advisable that the authorities take into account these results and try both: balance the disparities in income distribution with bigger and better job opportunities as the way to control the expansion of these areas more effectively, like for instance encouraging densification to the low and medium density areas in order to simplify the implementation of infrastructure, by means ofpersuade the population with visual material (maps, diagrams, photos) through TV, radio, lectures, chats, newsletters etc. notifying on the gravity of the situation which would help in raising awareness within communities.

Regarding the technology employed, the proper use of a Geographic Information System (GIS) allows an appropriate representation and graphic interpretation of spatiality effects in the settlements over time, thanks to which it is possible to point tendencies and easily work with all kind of restrictions with the help of thematic maps allowing the insertion of these settlement in a proper way in urban network.

It is important to note that using the ArcGIS platform to carry out the assessment of urban expansion in the studied areas, the work was simplified substantially, allowing easily comparisons on density and urban sprawl by towns as well asevaluations of possible environmental impacts. That is the reason why it is strongly recommend the use of this technology for the development of urban projects in general, trying to find free software that can save resources and simplify the work of professionals involved in the projects.

With the same vision, the EstudoTécnico demanded by Law 11,977 / 09 for mapping and environmental monitoring should be done with similar tools to help meet the requirements existing in this kind of projects. In that way it could be possible ensure a spatial monitoring in the areas to be occupied, in both urban and environmental dynamic, which could be analyzed in a systematic way in order to grant the opportunity to produce successfully proposals to implement a plan conforms to reality and keep balance with the principles of environmental sustainability and quality of life.

Finally, it must be understood that at the core of the problem are people like everyone else. People with rights to live with dignity, and to live with dignity is not only have a roof. House is not just a physical space, it is also necessary have access to work, and live in decent conditions, safe and provided with all the necessary infrastructure (water, sewage, transportation, health, education, among others) since "everyone has the right to a standard of living adequate for the health and wellbeing of himself and his family'... []" as proposed in the Universal Declaration of Human rights. 


\section{BIBLIOGRAPHIC REFERENCES}

ACSERALD, H. Sentidos da Sustentabilidade Urbana. In. A Duração das Cidades: sustentabilidade e risco nas políticas urbanas. Rio de Janeiro: DP\&A, 2001. p 27- 55.

ADASA-Agência Reguladora de Águas, Energia e Saneamento do Distrito Federal e GDFGoverno do Distrito Federal. 2012a.Zoneamento Ecológico-Econômico do Distrito Federal. Brasília-DF, 2012.

ADASA-Agência Reguladora de Águas, Energia e Saneamento do Distrito Federal. 2012b. Plano de Gerenciamento Integrado de Recursos Hídricos do Distrito Federal. Relatório Final. Volume 1. Diagnostico. Brasília-DF, 2012.

ANJOS, R. S. A. Modelagem da dinâmica espacial urbana no Distrito Federal do Brasil utilizando produtos de sensoriamento remoto e recursos de geoprocessamento In: Simpósio Brasileiro de Sensoriamento Remoto (SBSR), 1, 1993, Goiânia. Anais... São José dos Campos: INPE, 1993. Artigos, p.7-15.

BRASIL. Lein ${ }^{0}$ 10.257, de 10 de julho de 2001. Estatuto da Cidade. Brasília, 2001.

.Lein ${ }^{0}$ 11.977, de 07 de julho de 2009. Programa Minha Casa, Minha Vida - PMCMV. Brasília, 2009.

.Lein 12.608 , de 10 de abril de 2012. Política Nacional de Proteção e Defesa Civil PNPDEC. Brasília, 2012.

.Ministério das Cidades: Aliança das Cidades. O Estatuto da Cidade: comentado. CARVALHO, Celso (Org.) e ROSSBACH, Anaclaudia (Org). São Paulo, 2010.

.Ministério da Integração Nacional. 2011. Regiões Integradas de Desenvolvimento RIDEs.Disponível em:<http://www.mi.gov.br/web/guest/regioes_integradas_rides>Acesso em: 9 nov. 2015.

\begin{tabular}{llllll} 
& Região Integrada de Desenvolvimento do Distrito & Federal e Entorno - RIDE- \\
\hline DF.Regiões & Integradas & de & Desenvolvimento & -RIDEs.2015. & Disponível
\end{tabular} em:<http://www.mi.gov.br/regioes_integradas_df_> Acesso em: 11 ene. 2016.

.Subsecretaria de Estado da Ordem Pública e Social do Distrito Federal. Parcelamento Irregular do Solo. 2006. Disponível em: $<\mathrm{http}: / / \mathrm{www}$.seops.df.gov.br/frentes-de-fiscalizacao/201208-21-17-01-06/parcelamento-irregular-do-solo.html> Acesso em: 28 ene. 2016.

CAIADO, M.C.S.Estruturação intra-urbana e contrapartidas sociodemográficas: adiferenciação socioespacial da populaçãona região do Distrito Federal e entorno.Tese de doutorado. Campinas: IFCH/Unicamp, 2004.

CODO, Sandra. Os impactos da expansão urbana provocada pela exclusão social nas cidades indianas e brasileiras. IEA USP - Instituto de Estudos Avançados da Universidade de São Paulo. 2013. Disponível em: <http://www.iea.usp.br/noticias/os-impactos-da-expansao-urbana-provocadapela-exclusao-social-nas-cidades-indianas-e-brasileiras>. Acesso em: 14 nov. 2015.

CODEPLAN - Companhia de Planejamento do Distrito Federal. Pesquisa Distrital por Amostra de Domicílios - Brasília/Plano Piloto- PDAD/2014. Brasília (DF), 2014.

CUNHA,Ray. Ilha da Fantasia vive sitiada; onda de crimes apavora o cidadão. Notibras, 2014. Disponível em: <http://www.notibras.com/site/, ilha-da-fantasia-sitiada-onda-de-violencia-embrasilia-apavora-cidadao/html> Acesso em: 15fev. 2016.

FERREIRA, João Sette Whitaker. São Paulo: cidade da intolerância, ou o urbanismo "à Brasileira". 2011. Instituto de Estudos Avançados da Universidade de São Paulo. vol.25, n.71, p. 73-88. ISSN 0103-4014. São Paulo: USP, 2011.

Eletronic Magazine: Time - Techinique - Territorry, V.6, N.2 (2015), 51:70 ISSN: 2177-4366 
GOVERnO DE BRASíliA. População: Gente de Brasília. Site on-line. Disponível em: <http://www.brasilia.df.gov.br/index.php/2015/10/21/populacao/>. Acessoem: 10 nov. 2015.

HDR - HUMAN DEVELOPMENT REPORT 2014: Sustaining Human Progress: Reducing Vulnerability and Building Resilience. New York: United Nations Development Programme. 2014. f. 226.

HERRERA, D.J.M ; ALVES, C. M. A. Conflitos do uso do solo e seus efeitos na gestão dos recursos hídricos do Distrito Federal e seu entorno. In: XXI Simpósio Brasileiro de Recursos Hídricos, 2015, Brasília. Anais do XXI Simpósio Brasileiro de Recursos Hídricos. São Paulo: Associação Brasileira de Recursos Hídricos, 2015.

INSTITUTO BRASILEIRO DE GEOGRAFIA E ESTADÍSTICA - IBGE. Estudos e Pesquisas, informação Geográfica número 9. Indicadores de Desenvolvimento SustentávelBrasil 2012. Rio de Janeiro, 2012.

.Estimativa populacional 2014 IBGE. Estimativa populacional 2014. 1 de julho de 2014. Disponível em: <http://www.ibge.gov.br/home/estatistica/populacao/estimativa2014/>.Acesso em: 10sep. 2014.

.Sinopse do Censo Demográfico 2010. População. Disponível em: <http://www.censo2010.ibge.gov.br/sinopse/index.php?dados=4\&uf=00/>. Acesso em: 24 de ene. 2016.

MAGALHÃES, R.A.M. A construção da sustentabilidade urbana: obstáculos e perspectivas. Associação Nacional de Pesquisa e Pós-Graduação em Ambiente e Sociedade - ANPPAS, III. Anais. PROURB/UFRJ. Brasília, DF, maio. 2006.

MARICATO, E. Metrópole na periferia do capitalismo: ilegalidade, desigualdade e violência. São Paulo: Hucitec, 1996.

.Metrópole periférica, desigualdade social e meio ambiente. 2001. In: VIANA, Gilney; SILVA, Marina; DINIZ, Nilo (Org.). O desafio da sustentabilidade: um debate socioambiental no Brasil. São Paulo: Fundação Perseu Abramo, 2001. p. 215-232

MENEZES, P.Avaliação do efeito das ações antrópicas no processo de escoamento superficial e assoreamento na bacia do lago Paranoá. Dissertação de mestrado. Instituto de Geociências. Universidade de Brasília. 2010.

OBSERVATORIO DAS METROPOLIS. Instituto nacional de ciência y tecnologia. Evolução urbana em Brasília: segregação socioespacial e desigualdade. Publicação 2012.Disponível em: $<$ http://observatoriodasmetropoles.net/index.php?option=com_k2\&view=item\&id=351\%3Aevolu\% C3\%A7\%C3\%A3o-urbana-em-bras\%C3\%ADlia-segrega\%C3\%A7\%C3\%A3o-socioespacial-edesigualdade $\&$ Itemid $=169 \&$ lang=pt $>$. Acesso em: $23 \mathrm{fev} .2016$.

ONU.Indicadores de los objetivos de DesarrollodelMilenio. 2015. Disponível em: <http://mdgs.un.org/unsd/mdg/Host.aspx?Content=Indicators/OfficialList.htm>. Acesso em: 26 nov. 2015.

PESTANA, L. M. A Agenda Marrom: o planejamento urbano ambiental. Revista de Direito da Cidadevol.01, n01. ISSN 2317-7721 p. 95-141. UERJ, 2006.

PINTO, V, Carvalho. Ocupação irregular do solo urbano: o papel da legislação federal.Brasília : Senado Federal, Consultoria Legislativa, 2003.

RIBEIRO, Rômulo José da Costa. Análise do IBEU para a RIDE-DF e a AMB. 2013. Disponível em: <http://www.observatoriodasmetropoles.net/download/ibeu_ride_brasilia.pdf> Acesso em: 20fev. 2016. 
SCHUSSEL, Z.G.L. O desenvolvimento urbano sustentável - uma utopia possível? Revista Desenvolvimento e Meio Ambiente. Editora UFPR. n. 9, p. 57 - 67, jan/jun. 2004.

SILVEIRA, R.M. Gogoy. 500 anos de uma cidadania excludente. Revista Direitos Humanos. Disponível em: <http://www.dhnet.org.br/dados/livros/edh/br/pbunesco/iii_03_500anos.html> Acesso em: 10fev. 2016.

UNITED NATIONS. World Commission on Environment and Development. Report: Our Common Future. United Nations, 1987.

World Urbanization Prospects: The 2014 Revision, Highlights. New York: Department of Economic and Social Affairs, Population Division, 2014.

U.S.G.S. Department of the Interior U.S. Geological Survey.Disponível em: $<$ http://earthexplorer.usgs.gov>Acesso em:14mai.2014.

WORLD BANK. Objetivos de desarrollo del milenio. Objetivo 7: Garantizar la sostenibilidad del medio ambiente para 2015. Disponível em: <http://www.bancomundial.org/odm/medioambiente.html> Acesso em: 14ene.2014. 